\author{
공기 중 메틸에틸케톤 제어를 위한 Pilot-Scale \\ 흡수 시스템의 운영인자 분석 \\ 조완근 ${ }^{*}$ 김왕태 \\ 경북대학교 환경공학과 \\ (2011년 1월 8일 접수; 2011년 2월 8일 수정; 2011년 2월 19일 채택)
}

\title{
Analysis of Operation Parameters of Pilot-Scale Packed-Absorption System for Airborne Methyl Ethyl Ketone Control
}

\author{
Wan-Kuen Jo , Wang-Tae Kim \\ Department of Environmental Engineering, Kyungpook National University, Daegu 702-701, Korea \\ (Manuscript received 8 January, 2011; revised 8 February, 2011; accepted 19 February, 2011)
}

\begin{abstract}
Unlike many laboratory-scale studies on absorption of organic compounds (VOCs), limited pilot-scale studies have been reported. Accordingly, the present study was carried out to examine operation parameters for the effective control of a hydrophilic VOC (methyl ethyl ketone, MEK) by applying a circular pilot-scale packed-absorption system (inside diameter $37 \mathrm{~cm} \times$ height $167 \mathrm{~cm}$ ). The absorption efficiencies of MEK were investigated for three major operation parameters: input concentration, water flow rate, and ratio of gas flow-rate to washing water amount (water-to-gas ratio). The experimental set-up comprised of the flow control system, generation system, recirculation system, packed-absorption system, and outlet system. For three MEK input concentrations (300, 350, and $750 \mathrm{ppm}$ ), absorption efficiencies approached near $95 \%$ and then, decreased gradually as the operation time increased, thereby suggesting a non-steady state condition. Under these conditions, higher absorption efficiencies were shown for lower input concentration conditions, which were consistent with those of laboratory-scale studies. However, a steady state condition occurred for two input concentration conditions (100 and $200 \mathrm{ppm}$ ), and the difference in absorption efficiencies between these two conditions were insignificant. As supported by an established gas-liquid absorption theory, a higher water flow rate exhibited a greater absorption efficiency. Moreover, as same with the laboratory-scale studies, the absorption efficiencies increased as water-to-gas ratios increased. Meanwhile, regardless of water flow rates or water-to-gas ratios, as the operation time of the absorption became longer, the $\mathrm{pH}$ of water increased, but the elevation extent was not substantial (maximum $\mathrm{pH}$ difference, 1.1).
\end{abstract}

Key Words : Pilot-scale, Input concentration, Water-to-gas ratio, Water flow rate, Absorption efficiency, pH

\section{1. 서 론}

대기로 방출되는 메틸에틸케톤(methyl ethyl ketone,

*Corresponding author : Wan-Kuen Jo, Department of Environmental Engineering, Kyungpook National University, Daegu 702-701, Korea

Phone: +82-53-950-6584

E-mail: wkjo@knu.ac.kr
CAS 번호: 78-93-3)은 지방족 케톤류에 해당하며 인 체 유해성을 가질 뿐만 아니라 악취 오염을 유발시키 는 주요한 대기 오염물질 그룹에 해당된다. 특히, 메틸 에틸케톤은 호흡기, 피부, 눈의 자극을 유발할 수 있 고, 중추신경계에 영향을 주어 메스꺼움, 구토, 호흡곤 란, 두통, 졸음을 유발시키거나, 폐 손상을 유발시키고 장기적인 영향으로 마비 및 경련을 일으킬 수 있다 (USEPA, 2003). 나아가, 이 오염물질은 대표적인 악 
취 유발물질 중의 하나로서 악취 최소 감지농도는 5.4 $\mathrm{ppm}$ 으로 알려져 있다(Hudson 등, 2006; Pandey와 Kim, 2009; Verschueren, 1996). 이러한 환경적 중요 성을 지닌 메틸에틸케톤은 석유 및 석유화학공정, 염 색 및 섬유가공 공정, 페인트, 잉크, 탈수제, 인쇄잉크, 도금공업, 추출용제 등에서 주로 배출 되어 매우 넓은 지역에 산재하여 분포하기 때문에 대기 중 메틸에틸 케톤의 오염을 최소화하기 위해서는 배출 되기 전에 각 오염원을 제어하는 것이 가장 경제적이고 효과적 이다(Raghuvanshi와 Babu, 2009).

환경 악취 유발 및 유해성을 가진 메틸에틸케톤과 다른 휘발성유기화합물질(volatile organic compounds: $\mathrm{VOCs})$ 의 배출 제어를 위하여 소각, 오존화, 저온 열 촉매 분해, 플라즈마 광촉매, 흡수, 흡착 및 생물학적 여과법이 주로 이용되어 왔다(Arzamendi 등, 2009; Daubert-Deleris 등, 2006; Devinny 등, 2001; Durbray 와 Vanderschuren, 2004; $\mathrm{Wu}$ 등, 2001). 이들 전형적 인 제어방법들 각각이 장점과 단점을 모두 가지기 때 문에 배출되는 VOCs의 물리 및 화학적 특성에 따라 이들 기술 중 하나 또는 복수로 선정하여 장점은 최대 화하고 단점은 최소화하는 방향으로 적절하게 활용 될 수 있다(Wu 등, 2001). 특히, 메틸에틸케톤의 경우 물에 대한 용해도가 $27.5 \%$ 로서 다른 VOCs에 비해 친수성이 강하기 때문에 메틸에틸케톤의 효율적 오 염원 제어를 위하여 물을 이용한 흡수방법이 다른 기 술보다 경제적으로 활용될 수 있는 것으로 보고되었다 (Daubert-Deleris 등, 2006; Durbray와 Vanderschuren, 2004; $\mathrm{Wu}$ 등, 2001). 친수성 VOCs의 흡수법은 물 접 촉을 통해 배출가스 내 오염물질의 농도를 인체에 무 해한 수준으로 배출 시키는 방법으로서, 가스 흡수는 가스로부터 기/액 접촉면(gas-liquid interface)을 통과 하여, 최종적으로 액체 속으로 분산되는 물질의 확산 과정을 거친다(Daubert- Deleris 등, 2006; Durbray와 Vanderschuren, 2004). 이때 액체에 용해된 물질은 분 산이나 화학적인 반응을 동반 할 수 있고, 흡수과정은 분자확산이나 소용돌이확산(eddy diffusion)을 통한 물질 전달 현상이다. 소용돌이 확산은 분자확산과 비 교하여 매우 빠르게 작용하기 때문에 난류도를 증가 시켜 흡수 장치의 오염물질 흡수 효율을 증가시킬 수 있다 $(\mathrm{Wu}$ 등, 2001). 흡수법은 아세톤과 메틸알코올
같은 수용성 용매 회수, 지방 정제공장에서 악취가스 의 제거 등과 같이 다양한 산업체의 오염원 제어를 위해서 활용되어 왔다(Daubert-Deleris 등, 2006; Durbray와Vanderschuren, 2004).

그러나, 흡수법을 이용해서 친수성 VOCs를 처리할 경우 사용된 흡수액의 이차적인 처리가 부가적인 문 제로 대두되어 흡수법의 활용도가 제한되어 왔다 $(\mathrm{Wu}$ 등, 2001). 흡수법의 이러한 이차적인 문제점을 보완 하고 제어효율을 증대시키기 위하여, 최근에 기체-액 체의 질량전달(mass transfer) 단계의 최적화 방법이 제기되었다(Daubert-Deleris 등, 2006; Durbray와 Vanderschuren, 2004). 나아가, 흡수장치의 주요 운영 인자를 최적화함으로서 기체-액체의 질량전달을 최적 화할 수 있는 것으로 보고되었다(Daubert-Deleris 등, 2006; Durbray와 Vanderschuren, 2004). 비록 이들 선 행연구자들이 흡수장치 운영인자를 최적화하는 방법 에 대한 연구를 수행하였고, 오염물질의 가스 유량과 세정액 비율, 오염물질의 처리 농도 및 세정액의 유입 및 유출량이 주요 운영인자임이 제시되었지만, 이들 선행연구는 실험실 규모의 연구이거나 질량전달원리 를 적용한 이론적 연구로 제한되었기 때문에, 이들 선 행연구들의 결과를 검증하기 위해서, 보다 더 큰 규모 의 흡수장치에 대한 연구의 필요성이 제기되었다. 따 라서, 본 연구는 파일롯(pilot) 규모 충진흡수장치을 이용하여 친수성 메틸에틸케톤의 효율적 제어를 위한 주요 운영인자를 최적화하는 방법을 조사하기 위해서 수행되었다.

\section{2. 자료 및 방법}

\section{1. 운영인자}

본 연구는 원형 충전 흡수탑을 이용하여 친수성 휘 발성유기화합물인 메틸에틸케톤을 효율적으로 제어 하기 위해 요구되는 운영인자를 평가하였다. 선정된 조사 대상 운영인자는 흡수 과정의 세 가지 주요 운전 인자인 주입농도, 세정액의 유량 그리고 세정액 량과 처리가스 유량(액/가스)의 비 이다. 실제 배출업체에 서 배출되는 메틸에틸케톤의 농도가 100-1,000 ppm 임을 고려하여 현장 적용이 가능한 농도인 350 과 750 $\mathrm{ppm}$ 을 조사 대상 메틸에틸케톤 농도로 선정하였다. 
그러나, 이렇게 선정된 두 주입 농도 조건에서 흡수 효 율의 평형이 유지 되지 않았기 때문에 세 가지 낮은 주 입 농도 $(100,200$ 및 $300 \mathrm{ppm})$ 에서 추가적인 실험을 수행하였다. 온도에 따라 물의 메틸에틸케톤의 흡수 율이 달라지기 때문에, 본 연구에서는 온도를 $10^{\circ} \mathrm{C}$ 로 일정하게 유지한 정온상태에서 실험을 수행하였다. 흡수액의 경우 산업현장에서 쉽게 적용할 수 있도록 일반 상수원수를 사용하였다. 일반적인 세정수의 유 입 유량을 유지시키기 위해서 세정수 유입 유량은 100,280 또는 $480 \mathrm{~mL} / \mathrm{min}$ 으로 조절하였다. 또한, 흡 수탑 운영시 적용되는 액/가스의 적정 비가 $2-5 \mathrm{~L} / \mathrm{m}^{3}$ 이 기 때문에, 유입 가스량을 $1 \mathrm{~m} / \mathrm{min}$ 으로 유지하여, 액/ 가스 비가 2.5 또는 $4.8 \mathrm{~L} / \mathrm{m}^{3}$ 이 되게 유지시켰다.

\section{2. 실험 장치}

파일롯 규모 흡수장치 (내경 $37 \mathrm{~cm} \times$ 높이 $167 \mathrm{~cm}$ ) 의 메틸에틸케톤의 흡수효율을 평가하기 위한 실험 장치 개요도를 Fig. 1 에 나타내었다. 본 실험 장치는 유량 조절부, 오염물질 생성부, 반송부, 충전 흡수부, 배기부로 구성되었다. 메틸에틸케톤을 함유한 가스는 충전탑 하부에서 유입되어 상부로 이동하고 물은 상 부에서 유입되어 하부로 흘러 서로 역류시켜서 공기 에 섞여 있는 오염 가스가 물에 흡수되게 고안하였다. 또한 흡수장치의 내부 반응을 관찰하기 위하여 투명 아크릴 재질로 창문을 추가하였으며 가스 및 액 누출 방지를 위하여 각 조립부에 가스켓을 장착하였다. 유 량조절부는 공기 공급을 위한 공기 압축 펌프와 유량 계로 구성되어 있으며, 공기 압축 펌프에 의해 공급된

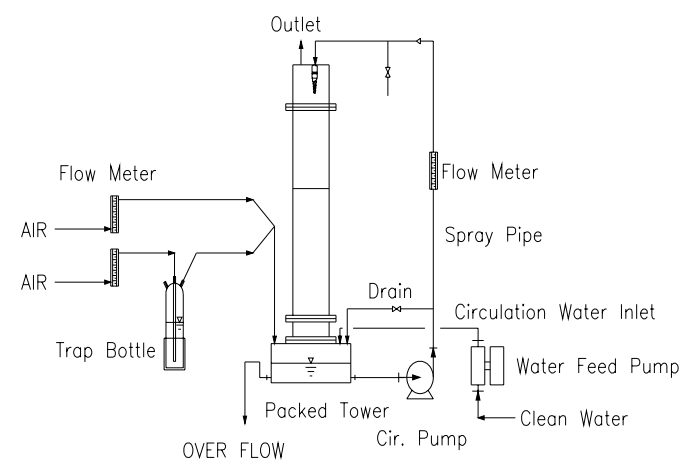

Fig. 1. Schematic diagram of the experimental apparatus.
공기는 유량계를 이용하여 유량을 조절하였다. 오염 물질 생성부는 흡수병과 공기 유입부로 구성되어 있 는데, 유입되는 공기의 양을 조절함으로써 일정한 농 도 생성 할 수 있게 고안하였다. 또한 흡수병에서 액상 의 시료가 충분히 기화하여 흡수 반응기 내로 유입될 수 있도록 하였다. 반송부는 유입부에서 유입되는 깨 끗한 유입수와 순환수조에서 순환펌프로 반송되는 반 송수를 이용하여 전체 흡수액을 공급하고, 유량계로 일정 유량을 유지시켰다. 충진 흡수부에서는 분사되 는 흡수액과 유입되는 가스사이의 반응이 더 잘 될 수 있게 표면적을 넓히기 위해 폴링(fall-ring)을 충전하 였고 순환수조에 $\mathrm{pH}$ 센서 및 온도계를 설치하여 순환 수조의 $\mathrm{pH}$ 와 온도 변화를 확인하였다. 충진제의 경우 접촉 효율 향상을 위해 $1 \mathrm{inch}$ 폴링을 채택하였고 폴 링의 직경이 $2.54 \mathrm{~cm}$ 이므로 홍수현상(flooding)을 방 지하기 위하여 흡수탑의 직경을 폴링 직경의 8 배 이상 인 $21 \mathrm{~cm}$ 로 제작하고, 충분한 반응 시간을 유지시키 기 위하여 충전제 높이를 $100 \mathrm{~cm}$ 로 결정하였다.

\section{3. 실험절차 및 방법}

충전 흡수 실험에 앞서 우선 반응기 내로 청정공기 를 30 분 이상 통과시켜 반응기 내에 잔류하거나 충전 재 표면에 흡수되어 있을지도 모르는 오염물질을 제 거하고, 반응기 유출구에서 가스상의 시료를 채취한 후 휴대용 측정기 (FoxoBoro, Model TVA-1000B)를 이용하여 오염물질의 농도가 검출되지 않는 것을 확 인하였다.

다음 단계에서, 흡수탑 내부의 공기 중 메틸에틸케 톤 농도를 일정하게 유지시키기 위하여 흡수병에 공 기를 주입하여 액상 표준물질을 기화시킨 다음 유량 조절용 공기와 혼합시켰다. 혼합가스가 일정 농도로 유지되는지를 확인되기 전에는 혼합가스를 충전탑 내 부로 바로 보내지 않고, 3-방향 밸브를 통해 배기시스 템으로 배출되게 하였다. 혼합 가스의 농도 평형상태 를 확인한 후에 3-방향 밸브의 방향을 전환하여 시료 가스를 충전탑 내부 부피의 10 배 정도가 되게 일정 유 량으로 충전탑을 통과시켰다. 이때, 충전탑의 유출구 에서 시료를 다시 채취 - 분석하여 주입 농도와 비교 하여 충전탑 내 오염물질의 농도가 평형상태인지 재 확인하였다. 이때 유량은 공기 인입 쪽에 설치된 유량 
계를 통하여 측정하였다. 충전 흡수탑을 통한 오염물 질 제거 실험은 평형 상태 확인 실험과 동일한 방법으 로 수행되었고, 주요 운전인자인 오염물질의 주입 농 도, 세정수의 유입 유량 및 액/가스 비 변화에 따른 메 틸에틸케톤의 제거 효율이 평가되었다.

충전탑 하부에서 위로 올라간 메틸에틸케톤 함유 가스는 충전층을 통과하면서 메틸에틸케톤이 제거되 고 배출관을 통해 외부로 배출되기 때문에 가스 시료 는 충전탑 상부 유입구와 하부 유출구 모두에서 채취 되었다. 시료채취를 위해 사용되는 테들라 백(Tedlar air bag)은 시료를 채취하기 전에 청정공기를 이용하 여 10 회 이상 세척하였고, 이 후 테들라 백 내부에 오염 물질이 남아있지 않은 것을 확인 한 다음 시료를 채취 하였다. 채취된 대상오염물질 시료는 불꽃이온화 센서 가 장착된 이동용 VOCs 자동 분석 장치인 휴대용 측정 기(FoxBoro TVA-1000B)를 이용하여 분석하였다.

\section{4. 자료의 질 검증(Quality Assurance and Quality Control)}

측정 자료의 신뢰성을 확보하기 위하여 자료의 질 검증 프로그램을 활용하였다. 이를 위하여 휴대용 $\mathrm{VOC}$ 측정기와 $\mathrm{GC}$ 를 동시에 사용하여 유입과 유출 농도를 측정하였다. 검량선 작성은 표준물질을 이용 하여 주 1 회 실시하였으며, 분석 전 표준물질을 이용 하여 실제 값 및 측정값의 오차율이 $5 \%$ 이내 인 것을 확인 후 대상오염물질 시료의 분석에 활용하였다. 본 연구의 반응장치는 실험에 앞서 10 분 이상 깨끗한 공 기를 흐르게 하여 반응장치 내부를 정화시킨 후 내부 의 오염여부에 대해 확인하였으며, 또한 깨끗한 세정 액으로 충분히 세정하여 오염이 되지 않은 것을 확인 하였다. 흡수탑 내부 벽과 충진제에 의한 흡착 효과를 확인하기 위하여 반송수 및 유입수를 공급하지 않은 조건에서 유입 가스 농도에 대한 유출 가스 농도 비를 분석 하였다. 유입 가스 농도는 실험 농도와 유사한 1000 과 $500 \mathrm{ppm}$ 두 가지이고, 유량은 실험조건과 같 이 $1 \mathrm{~m} / \mathrm{min}$ 로 유지 했으며, 흡수탑 내부 온도 역시 1 $0^{\circ} \mathrm{C}$ 로 유지 하였다. 시료 채취 역시 실험조건과 동일 하게 유입구와 유출구에서 각각 테들라 백으로 포집 후 분석하였다. 분석 결과 흡수장치 내부의 메틸에틸 케톤 흡착정도가 약 $25 \%$ 정도로 나타나, 미국 환경보
호국(USEPA)에서 정한 보정 미적용 범위인 $20 \%$ 를 초과하였다. 따라서, 흡수장치에 의한 메틸에틸케톤 의 흡수효율을 계산할 때, 흡수장치의 내부 흡착에 의 한 영향을 고려하여 보정값을 이용하였다.

\section{3. 결과 및 고찰}

\section{1. 주입 농도에 따른 흡수 효율}

파일롯-규모 흡수 시스템의 메틸에틸케톤 흡수 효 율에 대한 주입 농도 영향을 평가하기 위하여 2 단계 실험이 수행되었다. 세정수 유입 유량은 $280 \mathrm{~mL} / \mathrm{min}$ 으로, 액/가스 비는 $2.5 \mathrm{~L} / \mathrm{m}^{3}$ 로 고정되었고, 흡수탑 내 에서 측정된 온도는 $10 \pm 1{ }^{\circ} \mathrm{C}$ 이었다. 일 단계 실험에 서 얻은 두 가지 주입농도에 따른 시간대별 흡수 효율 을 Fig. 2에 나타내었다. 가동시간 5 분 후에는 주입농 도 350 과 $750 \mathrm{ppm}$ 에 대하여 흡수 효율이 모두 $95 \%$ 부근이었고, 가동시간 90 분 후에는 $73 \%$ 부근으로 나 타나 두 주입 농도 차이에 의한 흡수 효율 차이가 다소 있는 것으로 나타났다. 나아가, 가동 시간이 경과함에 따라 점진적으로 주입 농도에 따른 흡수 효율 차가 증 가하는 것으로 나타났다. 주입 농도 350 과 $750 \mathrm{ppm}$ 의 경우, 각각 가동 시간 180 과 120 분 정도에서 흡수 효율이 거의 제로에 가깝게 나타나 본 실험이 정상 상 태(steady state)에 도달하지 않은 것으로 판단되었다. 이러한 결과는 실험에 이용된 오염물질의 주입농도가

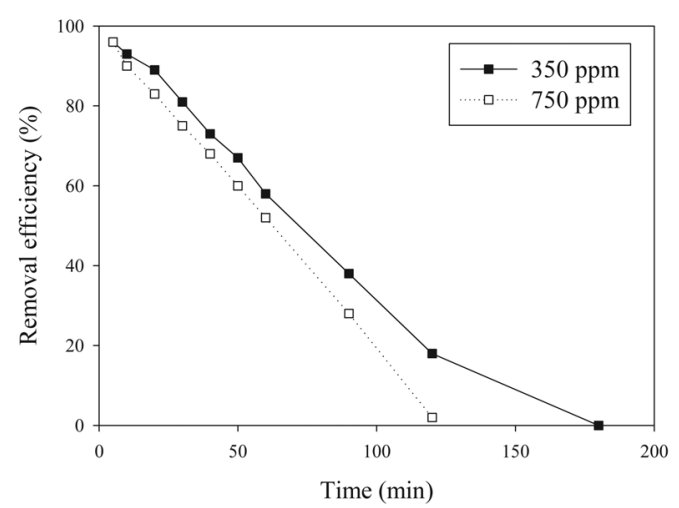

Fig. 2. Time-series removal efficiencies (\%) of methyl ethyl ketone for two input concentrations (350 and 750 $\mathrm{ppm}$ ): water flow rate, $480 \mathrm{~mL} / \mathrm{min}$; and water-gas ratios, $2.5 \mathrm{~L} / \mathrm{m}^{3}$. 
높아서 계획된 실험시간 이내에 오염물질의 액체 포 화상태가 이루어졌기 때문으로 판단되었다(Heymes 등, 2007). 따라서, 실제 흡수장치가 정상 상태로 운전 되는 연속흐름조작임을 고려하여, 정상 상태 조건에 서 본 연구 결과를 확인하기 위하여 보다 낮은 주입농 도를 이용한 2 단계 실험을 수행하였고, 이 결과를 Table 1에 나타내었다.

Table 1. Time-series removal efficiencies(\%) of MEK for two different water flow rates (FRs, 280 and $480 \mathrm{~mL} / \mathrm{min}$ ) according to the input concentrations*

\begin{tabular}{|c|c|c|c|c|}
\hline \multirow{2}{*}{ Time(min) } & \multirow{2}{*}{$\mathrm{FR}(\mathrm{mL} / \mathrm{min})$} & \multicolumn{3}{|c|}{ Removal efficiency(\%) } \\
\hline & & $100 \mathrm{ppm}$ & $200 \mathrm{ppm}$ & $300 \mathrm{ppm}$ \\
\hline \multirow{2}{*}{5} & 280 & 95.1 & 95.3 & 96.1 \\
\hline & 480 & 95.7 & 95.8 & 96.7 \\
\hline \multirow{2}{*}{10} & 280 & 95.3 & 95.7 & 94.3 \\
\hline & 480 & 95.1 & 95.2 & 95.1 \\
\hline \multirow{2}{*}{20} & 280 & 89.2 & 87.9 & 89.2 \\
\hline & 480 & 91.4 & 91.0 & 91.4 \\
\hline \multirow{2}{*}{30} & 280 & 91.0 & 89.7 & 91.0 \\
\hline & 480 & 91.3 & 90.9 & 86.3 \\
\hline \multirow{2}{*}{40} & 280 & 89.7 & 90.4 & 87.7 \\
\hline & 480 & 90.5 & 91.1 & 88.0 \\
\hline \multirow{2}{*}{50} & 280 & 89.2 & 91.4 & 83.2 \\
\hline & 480 & 90.5 & 90.1 & 86.5 \\
\hline \multirow{2}{*}{60} & 280 & 91.5 & 88.9 & 82.5 \\
\hline & 480 & 90.7 & 90.1 & 85.7 \\
\hline \multirow{2}{*}{70} & 280 & 89.7 & 88.7 & 83.7 \\
\hline & 480 & 89.9 & 89.3 & 84.7 \\
\hline \multirow{2}{*}{80} & 280 & 90.3 & 90.7 & 83.3 \\
\hline & 480 & 91.1 & 89.8 & 84.1 \\
\hline \multirow{2}{*}{90} & 280 & 91.4 & 92.1 & 81.4 \\
\hline & 480 & 90.5 & 91.9 & 83.5 \\
\hline \multirow{2}{*}{120} & 280 & 89.5 & 89.7 & na \\
\hline & 480 & 91.4 & 88.9 & na \\
\hline \multirow{2}{*}{180} & 280 & 90.5 & 91.3 & na \\
\hline & 480 & 89.7 & 90.3 & na \\
\hline
\end{tabular}

*na, not available.

Table 1은 두 개의 다른 세정수 유입 유량 조건에서 세 가지 주입농도에 따른 시간대별 파일롯-규모 흡수 시스템의 메틸에틸케톤 흡수 효율을 나타낸다. 주입 농도 $300 \mathrm{ppm}$ 에 대해서는 일 단계 실험 결과와 유사 하게 두 세정수 유입 유량 조건 모두에서 메틸에틸케 톤에 대한 흡수 효율이 가동시간이 경과함에 따라 점 진적으로 감소하는 것으로 나타났다. 그러나, 1 단계
실험과는 달리 계획된 실험 시간 동안에는 흡수 효율 이 제로에 도달하지는 않았다. 주입농도 $300 \mathrm{ppm}$ 에 대한 이러한 결과는 주입농도가 1 단계 실험에 이용된 350 과 $750 \mathrm{ppm}$ 보다 낮아서, 메틸에틸케톤의 액체 포 화 시기는 다소 늦추어졌기 때문으로 추정된다 (Heymes 등, 2007). 주입농도 $300 \mathrm{ppm}$ 을 이용한 실 험과는 달리, 낮은 두 주입농도(100 및 $200 \mathrm{ppm)}$ 를 이 용한 실험에서는 흡수 시스템 가동 초기에는 두 세정 수 유입 유량 모두에 대하여 흡수 효율이 $95 \%$ 부근에 유지되었고, 가동 시간 20 분 정도에서 흡수 효율이 $90 \%$ 부근으로 다소 감소한 이 후에 계획된 실험시간 동안 흡수 효율이 거의 일정하게 나타나 흡수 효율의 정상상태가 유지되었다. 또한, 낮은 두 주입농도(100 및 $200 \mathrm{ppm}$ )를 이용하여 수행된 연구에서 두 농도 상 호 간에 흡수효율 차이는 미미한 것으로 나타났다. 선 행연구(Heymes 등, 2007; Ozturk와Yilmaz, 2006)에 서 지적된바와 같이 VOCs를 흡수 처리시 유입 농도 가 높을 수록 가스에서 물로의 질량전달 속도가 증가 하고 이로 인해 높은 유입 농도의 처리효율이 높아질 수 있지만, 역으로 시간이 경과함에 따라 처리수내의 높은 농도로 인해 가스상으로 확산 속도가 증가할 수 있으므로 상기 본 연구 결과는 기-액과 액-기 방향 질 량전달속도 차이 때문으로 이해된다. 비록, 실험실 규 모의 연구결과이지만, Ozturk와 Yilmaz(2006)는 이러 한 현상이 벤젠과 톨루엔과 같은 소수성 VOCs보다 메탄올과 같은 친수성 $\mathrm{VOCs}$ 에 두드러지게 나타나는 것으로 보고하였다. 나아가, Heymes 등(2007)과 Patrick(1994)도 메틸에틸케톤은 아니지만 실험실 규 모의 다른 VOCs의 흡수 효율 실험에서도 유사한 농 도 영향을 나타낸 것으로 보고하였다. 따라서, 주입농 도에 대한 흡수 효율 영향 측면에서, 본 연구에서 얻은 파일롯-규모의 메틸에틸케톤 흡수 장치의 결과가 실 험실 규모의 다른 VOCs에 대한 선행연구 결과와 일 치하는 것으로 나타났다.

\section{2. 세정수의 유입 유량에 따른 흡수 효율}

Fig. $3 \mathrm{a}$ 와 $3 \mathrm{~b}$ 에 각각 주입 농도 350 과 $750 \mathrm{ppm}$ 조 건에서 얻은 파일롯-규모 흡수장치의 세정수 유입 유 량의 변화에 따른 메틸에틸케톤의 흡수 처리 효율을 나타내었다. 주입 농도 350 과 $750 \mathrm{ppm}$ 모두에 대하 여, 해당 가동시간동안에, 세정수 유입 유량이 증가함 


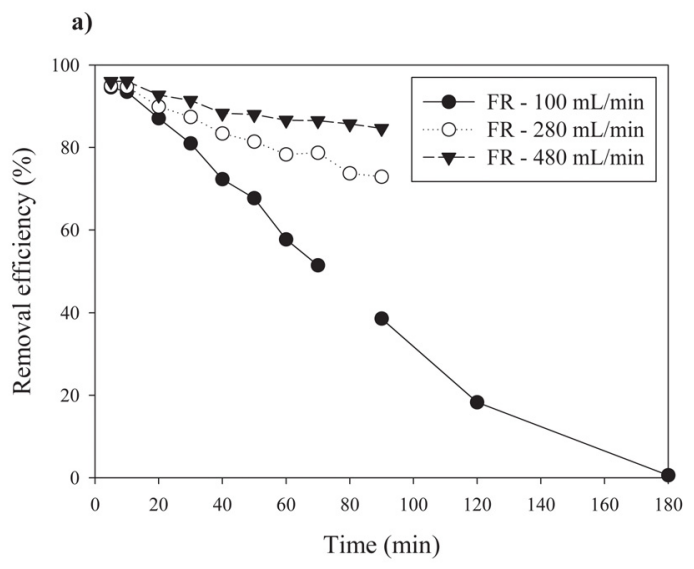

b)

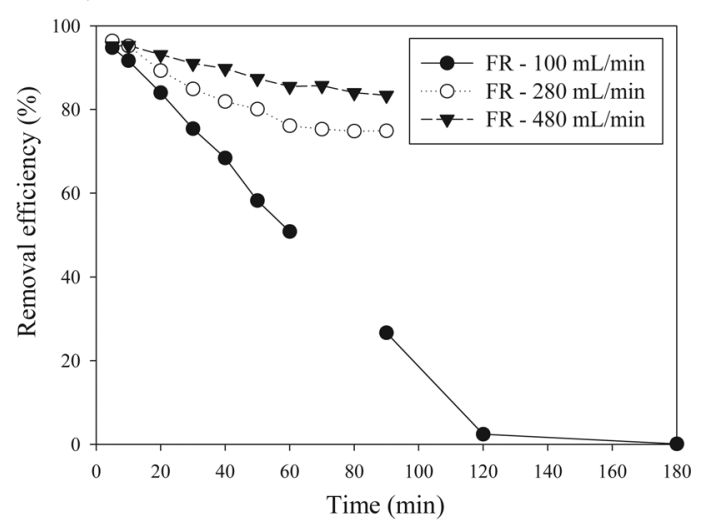

Fig. 3. Time-series removal efficiencies (\%) of methyl ethyl ketone for three water flow rates (FRs) $(100,280$, and $480 \mathrm{~mL} / \mathrm{min}$ ) for a) $350 \mathrm{ppm}$ and b) $750 \mathrm{ppm}$ : water-gas ratios, $2.5 \mathrm{~L} / \mathrm{m}^{3}$.

에 따라 흡수효율도 증가하는 것으로 나타났다. 세정 수 유입 유량이 가장 낮은 경우에는 가동시간 5분 후 에 주입농도 350 과 $750 \mathrm{ppm}$ 모두에 대하여 흡수 효율 이 $95 \%$ 부근이었던 것이 가동시간 90 분 후에 흡수 효 율이 각각 $39 \%$ 와 $27 \%$ 부근으로 대폭 감소하였고, 가 동시간이 180 분이 되었을 때는 흡수 효율이 대폭 감 소하여 흡수 능력을 거의 상실하는 것으로 나타났다. 반면에 세정수 유입 유량이 $280 \mathrm{~mL} / \mathrm{min}$ 의 경우에는, 가동시간 5 분 후에 주입농도 350 과 $750 \mathrm{ppm}$ 모두에 대하여 흡수 효율이 $95 \%$ 부근이었고, 가동시간이 90 분이 되어도 흡수 효율이 각각 $73 \%$ 부근으로서 어느 정도의 흡수 능력을 가지는 것으로 나타났다. 나아가,
세정수 유입 유량이 $480 \mathrm{~mL} / \mathrm{min}$ 의 경우에는, 가동시 간 5 분 후에 주입농도 350 과 $750 \mathrm{ppm}$ 모두에 대하여 흡수 효율이 $95 \%$ 부근이었고, 가동시간이 90 분이 되 었을 때 흡수 효율이 각각 $84 \%$ 부근을 유지하여 세정 수 유입 유량 $280 \mathrm{~mL} / \mathrm{min}$ 의 경우보다도 높게 나나났 다. 이러한 결과는 다음과 같이 기체-액체 물질전달 원리에 의해서 설명된다(Merchuk 등, 2007; NavarroLaboulais 등, 2008). 액체와 기체 흐름 사이에서 물질 전달이 일어날 경우, 분자확산과 난류확산의 복합 효 과로 나타나고, 물질전달속도는 다음과 같이 표현된 다(Boltes 등, 2008; Yin 등, 2009):

$$
\mathrm{V}_{\mathrm{m}}=\mathrm{k}_{\mathrm{W}}\left(\mathrm{C}_{\text {MEKB }}-\mathrm{C}_{\text {MEKW }}\right)=\mathrm{k}_{\mathrm{G}}\left(\mathrm{C}_{\text {MEKG }}-\mathrm{C}_{\text {MEKB }}\right)
$$

여기서, $\mathrm{V}_{\mathrm{m}}$ 은 물질전달속도, $\mathrm{k}_{\mathrm{W}}$ 는 농도에 기초한 액상의 물질전달계수, $\mathrm{C}_{\mathrm{MEKB}}$ 는 액상 경계면에서 메 틸에틸케톤의 농도, $\mathrm{C}_{\mathrm{MEKW}}$ 는 액상본체에서 메틸에틸 케톤의 농도, $\mathrm{k}_{\mathrm{G}}$ 는 농도에 기초한 기상의 물질전달계 수, $\mathrm{C}_{\mathrm{MEKG}}$ 는 기상본체에서 메틸에틸케톤의 농도, 그 리고 $\mathrm{C}_{\mathrm{MEKB}}$ 는 기상 경계면에서 메틸에틸케톤의 농도 를 나타낸다. 세정수 유입이 없는 경우에는 흡수장치 가동시간이 증가함에 따라 액상 본체의 농도가 증가 하므로 $\mathrm{C}_{\mathrm{MEKW}}$ 값 증가로 인하여 $\left(\mathrm{C}_{\mathrm{MEKB}}-\mathrm{C}_{\mathrm{MEKW}}\right)$ 값이 작아져서 $\mathrm{V}_{\mathrm{m}}$ 값이 감소하여 결과적으로 흡수 처리효 율이 낮아지게 된다. 반면에, 세정수의 유입 유량이 증 가하게 되면 희석에 의하여 $\left(\mathrm{C}_{\mathrm{MEKB}}-\mathrm{C}_{\mathrm{MEKW}}\right)$ 값이 증가 하여 $\mathrm{V}_{\mathrm{m}}$ 값이 증가하게 되고 결과적으로 세정수 유입 이 낮을 때 보다 흡수 처리효율이 높아지게 된다. 따라 서, 본 연구에서 얻은 파일롯-규모의 메틸에틸케톤 흡 수 장치의 결과는 일반 VOCs에 대한 흡수 이론과 일 치하는 것으로 나타났다.

\section{3. 액/가스 비에 따른 흡수 효율}

액/가스의 비를 선정하는 것이 메틸에틸케톤의 흡 수 효율 뿐만 아니라 세정수 사용에 따른 운영 비용과 도 직접적으로 관련이 있기 때문에 흡수 장치 운영시 적정 액/가스 비에 흡수 효율 변화는 반드시 고려되어 야한다. 따라서, 실제 산업 현장에서 충전 흡수탑에 사 용되는 액/가스 비를 적용하기 위해 충전탑의 액/가스 비를 $2.5 \mathrm{~L} / \mathrm{m}^{3}$ 과 $4.8 \mathrm{~L} / \mathrm{m}^{3}$ 로 선정하여 세 가지 다른 세 


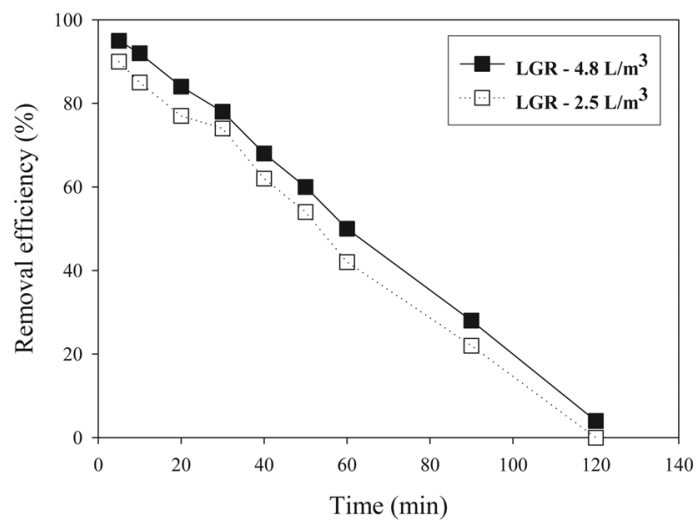

Fig. 4. Time-series removal efficiencies (\%) of methyl ethyl ketone for two different water-gas ratios (LGR, 2.5 and $\left.4.8 \mathrm{~L} / \mathrm{m}^{3}\right)$ : input concentration, $750 \mathrm{ppm}$ and water flow rate, $100 \mathrm{~mL} / \mathrm{min}$.

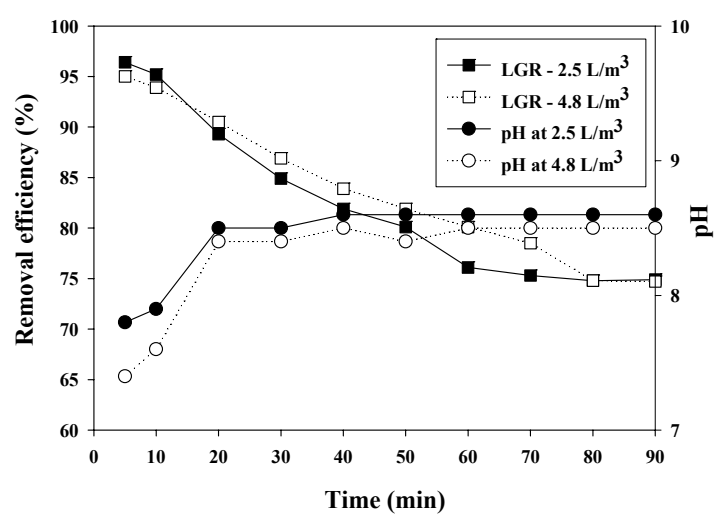

Fig. 5. Time-series removal efficiencies (\%) of methyl ethyl ketone and $\mathrm{pH}$ for two different water-gas ratios (LGR, 2.5 and $4.8 \mathrm{~L} / \mathrm{m}^{3}$ ): input concentration, 750 ppm and water flow rate, $280 \mathrm{~mL} / \mathrm{min}$.

정수 유입 유량 조건에서 메틸에틸케톤의 흡수 효율 을 조사하였다. 흡수 효율이 처리 대상 오염물질의 농 도와 온도의 함수이기도 하기 때문에 메틸에틸케톤의 주입 농도는 $750 \mathrm{ppm}$ 이고, 흡수탑 내 온도는 $10 \pm 1{ }^{\circ} \mathrm{C}$ 로 유지되었다. Figs. 3, 4 및 5는 각각 세정수 유입 유 량 100,280 , 및 $480 \mathrm{~mL} / \mathrm{min}$ 조건에서 액/가스 비에 따른 메틸에틸케톤의 시간대별 흡수 효율 변화를 나 타낸다. Fig. 3에서, 가동 시간 전체에서 액/가스 비가 $4.8 \mathrm{~L} / \mathrm{m}^{3}$ 의 경우가 액/가스 비가 $2.5 \mathrm{~L} / \mathrm{m}^{3}$ 의 경우 보다 다소 높게 나타나기는 하지만, 큰 차이를 나타내지는
않았다. 액/가스 비가 2.5 와 $4.8 \mathrm{~L} / \mathrm{m}^{3}$ 일 때 가동 시간 5 분 후에 흡수 효율이 각각 $95 \%$ 와 $92 \%$ 부근이고, 가동 시간 120 분 후에는 흡수 효율이 모두 거의 제로에 가 까웠다. Figs. 4 와 5 에서 각각 나타난 바와 같이, 세정 수 유입 유량이 280 및 $480 \mathrm{~mL} / \mathrm{min}$ 인 경우에도, 가동 시간 전체에서 액/가스 비가 $4.8 \mathrm{~L} / \mathrm{m}^{3}$ 의 경우가 액/가 스 비가 $2.5 \mathrm{~L} / \mathrm{m}^{3}$ 의 경우 보다 다소 높게 나타났다. 이 러한 결과는 특정 액/가스 비의 범위에서 충진 흡수탑 의 운영시 액/가스 비가 흡수 효율에 영향을 미치는 주 요 인자라는 실험실 규모에서 수행된 선행연구 결과 (Boltes 등, 2008; Yin 등, 2009)와 일치하는 것으로 나타났다. 비록 본 연구에서는 파일롯-규모의 흡수 장 치의 메틸에틸케톤의 흡수 효율에 영향을 미칠 수 있 는지 확인하는 연구 목적으로 두 종류의 액/가스 비 (4.8과 $2.5 \mathrm{~L} / \mathrm{m}^{3}$ 을)만을 조사하였지만, 실제 흡수 장치 운영시 경제성을 고려할 때, 제어 효율이 유사하면서 낮은 액/가스 비를 선정하기 위한 보다 다양한 액/가 스 비에 의한 흡수 장치의 흡수 효율 평가에 대한 후속 연구가 추천된다.

한편, 흡수 장치의 처리수를 2 차적인 생물학적으로 처리할 때, 물의 $\mathrm{pH}$ 가 주요한 인자이고(Dosta 등, 2008; El Hajjouji 등, 2008), 수중에서 알칼리성을 나 타내는 메틸에틸케톤이 물에 흡수가 진행되면서 물의 $\mathrm{pH}$ 가 변화할 가능성이 있기 때문에(Glowa 등, 2000), 메틸에틸케톤의 흡수 장치 유출부 가스 농도 뿐만 아 니라, 처리수의 $\mathrm{pH}$ 도 측정하였다. Figs. 5 와 6은 두 가 지의 다른 액/가스 비에 대하여 각각 세정수의 유입 유 량이 280 과 $480 \mathrm{~mL} / \mathrm{min}$ 의 조건에서 흡수 장치 가동 시간대별 $\mathrm{pH}$ 변화를 나타낸다. 세정수 유입 유량이 $280 \mathrm{~mL} / \mathrm{min}$ 인 조건에서는 $\mathrm{pH}$ 가 흡수 장치 가동 5 분 후에 액/가스 비 2.5 와 $4.8 \mathrm{~L} / \mathrm{m}^{3}$ 에 대하여 각각 7.8 과 7.4 이던 것이 흡수 장치 가동 90 분 후에는 각각 8.6 과 8.5 로서 액/가스 비에 따른 PH 변화도 크지 않은 것으 로 나타났다. 세정수 유입 유량이 $480 \mathrm{~mL} / \mathrm{min}$ 인 조건 에서도 유사한 $\mathrm{pH}$ 변화가 나타났다. 한편, 흡수 장치 가동 시간대별 $\mathrm{pH}$ 변화와 흡수 효율 관계를 살펴보면, $\mathrm{PH}$ 증가에 따라 메틸에틸케톤의 흡수 효율이 점차 감 소하는 것으로 나타났다. 이러한 상관관계는 흡수 효 율이 $\mathrm{pH}$ 의 영향을 받는 것인지, 아니면 앞에서 언급 된바와 같이 흡수 장치 가동시간이 증가하면서 메틸 


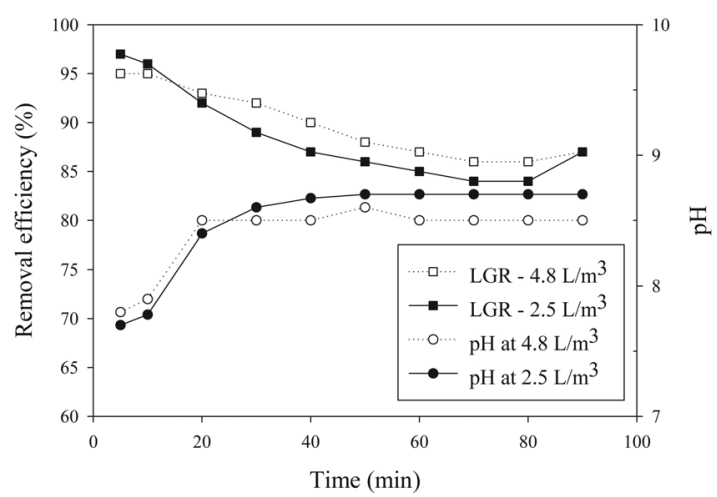

Fig. 6. Time-series removal efficiencies (\%) of methyl ethyl ketone and $\mathrm{pH}$ for two different water-gas ratios (LGR, 2.5 and $4.8 \mathrm{~L} / \mathrm{m}^{3}$ ): input concentration, 750 ppm and water flow, $480 \mathrm{~mL} / \mathrm{min}$.

에틸케톤이 물에 더 많이 용해되고 이로 인한 기-액 질량전달효과 때문인지는 확실하지 않다. 비록, 차후 검증이 필요하지만, 흡수 장치 가동 시간이 증가함에 따라 $\mathrm{pH}$ 변화가 일어나지만 증가 폭이 크지 않다는 점에서 이 정도의 $\mathrm{pH}$ 차이가 메틸에틸케톤의 용해도 에 영향을 미치기 보다는 후자의 설명이 더 적합한 것 으로 사료된다. 나아가, 이정도의 $\mathrm{pH}$ 증가는 처리수 의 2 차 처리에도 큰 영향을 미치지는 않는 것으로 판 단된다(Dosta 등, 2008; El Hajjouji 등, 2008).

\section{4. 결 론}

본 연구는 파일롯-규모의 흡수 장치를 이용하여 친 수성인 메틸에틸케톤의 흡수 효율에 영향을 미치는 주요 운영 인자 즉 유입 가스에 대한 오염물질의 처리 농도, 세정수 유입 유량 및 액/가스 비에 대해 조사하 였다. 높은 세 가지 주입농도 조건(300, 350 및 750 $\mathrm{ppm}$ )에서는, 가동 시간이 경과함에 따라 점진적으로 주입 농도에 따른 흡수 효율 차가 증가하는 것으로 나 타났다. 그러나, 낮은 두 가지 주입농도(100 및 200 $\mathrm{ppm})$ 의 경우, 높은 주입농도 조건과는 달리, 흡수 시 스템 가동 초기에는 흡수 효율이 다소 감소 추세를 보 였으나, 남은 실험시간 동안에는 흡수 효율이 거의 일 정하게 나타나 흡수 효율의 정상상태가 유지되었고, 두 낮은 농도 조건 상호 간에는 흡수 효율 차이가 크지
않은 것으로 나타났다. 파일롯규모의 메틸에틸케톤 흡수 시스템을 이용하여 얻은 이러한 결과는 실험실 규모의 다른 VOCs에 대한 선행연구 결과와 일치하는 것으로 나타났다. 또한, 파일롯규모 흡수 장치의 세 정수 유입 유량의 변화에 따른 메틸에틸케톤의 흡수 처리 효율 실험에서, 해당 가동시간 동안에 세정수 유 입 유량 증가에 따라 흡수 효율도 증가하는 것으로 나 타나, 일반 VOCs에 대한 흡수 이론과 일치하는 것으 로 나타났다. 파일롯-규모 흡수 장치를 이용한 본 실 험에서도, 가동 시간 전체에서 높은 액/가스 비 조건에 서 흡수 효율이 높게 나타나, 실험실-규모 흡수 장치 를 이용한 선행연구 결과와 일치하는 것으로 나타났 다. 한편, 세정수 유입 유량과 액/가스 비에 관계없이 흡수 장치 가동시간이 증가함에 따라 처리수의 $\mathrm{pH}$ 도 증가하지만, 증가 폭이 크지는 않은 것으로 나타나, 파 일롯-규모의 흡수장치를 이용하는 경우에도 처리수의 $\mathrm{pH}$ 가 흡수 효율에 큰 영향을 미치지는 않는 것으로 판단된다.

\section{참 고 문 헌}

Arzamendi, G., de la Peńa O'Shea, V. A., ÁlvarezGalván, M. C., Fierro, J. L. G., Arias, P. L., Gandía, L. M., 2009, Kinetics and selectivity of methyl-ethyl-ketone combustion in air over alumina-supported $\mathrm{PdO}_{\mathrm{x}}-\mathrm{MnO}_{\mathrm{x}}$ catalysts, J. Catal., 261, 50-59.

Boltes, K., Caro, A., Leton, P., Rodriguez, A., GarciaCalvo, E., 2008, Gas-liquid mass transfer in oil-water emulsions with an airlift bio-reactor, Chem. Eng. Proc., 47, 2408-2412.

Daubert-Deleris, I., Hoffmann, P. A., Fonade, C., Maranges, C., 2006, Hydrodynamic and mass transfer performance of a new aero-ejector with its application to VOC abatement, Chem. Eng. Sci., 61, 4982-4993.

Devinny, J. S., Deshusses, M. A., Webster, T. S., 2001, Biofiltration for Air Pollution Control, Lewis Publishers, Boca Raton, 3-8.

Dosta, J., Rovira, J., Galí, A., Macé, S., Mata-Álvarez, J., 2008, Integration of a Coagulation/Flocculation step in a biological sequencing batch reactor for 
COD and nitrogen removal of supernatant of anaerobically digested piggery wastewater, Biores. Technol., 99, 5722-5730.

Dubray, A., Vanderschuren, K., 2004, Mass transfer phenomena during sorption of hydrophilic volatile organic compounds into aqueous suspensions of activated carbon, Sep. Puri. Technol., 38, 215-223.

El Hajjouji, H., Bailly, J. R., Winterton, P., Merlina, G., Revel, J. C., Hafidi, M., 2008, Chemical and spectroscopic analysis of olive mill waste water during a biological treatment, Biores. Technol., 99, 4958-4965.

Glowa, G., Driver, P., Wren, J. C., 2000, Irradiation of MEK $Ð$ II: A detailed kinetic model for the degradation of 2-butanone in aerated aqueous solutions under steady-state g-radiolysis conditions, Rad. Phys. Chem., 58, 49-68.

Heymes, F., Demoustier, P. M., Charbit, F., Fanlo, J. L., Moulin, P., 2007, Treatment of gas hydrophobic VOCs by a hybrid absorption-pervaporation process: The case of toluene, Chem. Eng. Sci., 62, 2576-258.

Hudson, R., Arriola, A., Martínez-Gómez, M., Distel, H., 2006, Effect of air pollution on olfactory function in residents of Mexico city, Chem. Senses, 31, 79-85.

Merchuk, J. C., Rosenblat, Y., Berzin, I., 2007, Fluid flowand mass transfer in a counter-current gas - liquid inclined tubes photo-bioreactor, Chem. Eng. Sci., 62, 7414-7425.

Navarro-Laboulais, J., Cardona, S. C., Torregrosa, J. J., Abad, A., López, F., 2008, Practical identifiability analysis in dynamic gas-liquid reactors optimal experimental design for mass-transfer parameters determination, Comp. Chem. Eng., 32, 2382-2394.
Ozturk, B., Yilmaz, D., 2006, Absorptive removal of volatile organic compounds from flue gas streams, Proc. Safety Environ. Protect., 84, 391-398.

Pandey, S. K., Kim, K. H., 2009, Simulteneous determination of odorous volatile organic compounds with gas chromatography and a thermal desorber: A case study on methyl ethyl ketone, methyl isobutyl ketone, butyl acetate, and xylene, Microchem. J., 91, 245-252.

Patrick, D. R., 1994, Toxic Air Pollution Handbook, Van Nostrand Reinhold, NY, 390-397.

Raghuvanshi, S., Babu, B. V., 2009, Experimental studies and kinetic modeling for removal of methyl ethyl ketone using biofiltration, Biores. Technol., 100, 3855-3861.

USEPA (United States of Environmental Protection Agency), 2003, Toxicological review of methyl ethyl ketone (CAS No. 78-93-3), In Support of Summary Information on the Integrated Risk Information System (IRIS), 1-99.

Verschueren, K., 1996, Handbook of Environmental Data on Organic Chemicals, 3rd ed., Van Nostrand Reinhold, New York, 1292-1294.

Wu, H. H., Lin, S. S., Lai, C. C., 2001, Control of volatile organic compounds (VOC) from semiconductor manufacturing industry by wet scrubbing and ozonation, Proceedings of the Air \& Waste Management Association's Annual Conference \& Exhibition, Pittsburg, PA, 24-28.

Yin, Y., Zhang, X., Peng, D., Li, X., 2009, Model validation and case study on internally cooled/ heated dehumidifier/regenerator of liquid desiccant systems, Int. J. Therm. Sci., 48, 1664-1671. 